\title{
Comment
}

\section{The Importance of Having Rights}

$\begin{array}{lr}\text { I. Introduction } & 7\end{array}$

II. What are Rights? $\quad 8$

III. The Rationale of Fundamental (Human) Rights 10

IV. Ongoing Extensions of Human Rights 11

1. Which Rights? 11

2. The Oozing of Human Rights all Over International Law 12

3. Rights Against Whom? - New Duty Bearers 13

4. Where do Rights Reach? 14

5. Rights Holders: Rights for Whom? 14

V. Critiques of Rights 15

$\begin{array}{ll}\text { VI. Reasons for the Backlash } & 18\end{array}$

VII. Response: The Work and Benefits of Rights 19

$\begin{array}{lr}\text { VIII. Conclusions } & 22\end{array}$

\section{Introduction}

"The balloon of human rights has certainly popped, but there is no alternative and compelling idiom to fight injustice and mass catastrophes", writes the Kenyan-American Professor Makau Mutua, from a critical Third World Approaches to International Law (TWAIL) perspective. ${ }^{1}$ Let us compare the report of the United States (US) Commission on Unalienable Rights, released in August 2020.2 The report writes: "There is good reason to worry that the prodigious expansion of human rights has weakened rather than strengthened the claims of human rights and left the most disadvantaged more vulnerable. More rights do not always yield more justice." 3 This is a rare example of consensus among a TWAIL scholar and a Catholic-dominated conservative think group. If both agree on the overstretch of rights, we should take their finding seriously.

\footnotetext{
1 Makau Mutua, 'Is the Age of Human Rights Over?' in: Sophia A. McClennen and Alexandra Schultheis Moore (eds), The Routledge Companion to Literature and Human Rights (London: Routledge 2016), 450-458 (454). TWAIL stands for third world approach to international law.

2 This commission had been established by the US Secretary of State, Michael Pompeo, a member of the Republican party. Its chair was the Harvard professor Mary Ann Glendon, who had also served as the US ambassador to the Holy See.

3 Report of the Commission on Unalienable Rights of 26 August 2020, p. 38, <https:// www.state.gov>.
} 
Have rights, especially human rights, been so overused that we need an alternative legal language to combat injustice? This essay argues that the balloon has certainly been blown up quite a lot but that it has not yet popped - surely not for those who are right-less. Rather, pricking the needle into the balloon is a cheap intellectual exercise for those who are enjoying rights. I argue that we need complements but not alternatives to rights, because rights perform valuable practical functions and notably trigger obligations of those in power to justify their behaviour. Rights, especially human rights, may be "not enough", ${ }_{4}$ but they are a necessary and indeed indispensable legal instrument for protecting weak and vulnerable members of a society in which I include animals.

\section{What are Rights?}

Rights have been and are being discussed by political philosophers as moral rights. This paper is about legal rights which of course build on the moral pedigree of rights but which have the binding force of law. Technically speaking, we can distinguish rights as subjective entitlements from objective protective standards, the law. Just like English, the Roman legal language had two different words, ius as opposed to lex. The Roman terminology in reality does not fully match the contemporary distinction between law and rights ${ }^{5}$ but it is an easy marker to remember the distinction.

The difference between these two types of legal institutions can be explained with the following example: You are prohibited by law from scribbling on the painting of Mona Lisa. However, Mona Lisa has no right not to be scribbled upon. She cannot have such a right because she is no person in terms of the law but only a thing.

In modern law, roughly speaking since Immanuel Kant, legal rights are considered to be the basis of the legal duties owed to the rights-holders by others. ${ }^{6}$ For example, I have an intellectual property right over the content of this essay and readers are obliged to respect it and may not plagiarise me. It is not the other way round that my right flows from the readers' duty. That sounds technical, but it actually makes an important difference because it leads to a quite open-ended quality of my intellectual property right. It is not

4 Samuel Moyn, Not Enough: Human Rights in an Unequal World (Cambridge Mass.: Harvard University Press 2018).

5 Charles Donahue, 'Ius in the Subjective Sense in Roman Law: Reflections on Villey and Tierney' in: Domenico Maffei and Italo Birocchi (eds), A Ennio Cortese Vol. 1 (Rome: Il Cigno Edizioni 2001), 506-535.

6 Marietta Auer, 'Subjektive Rechte bei Pufendorf und Kant', Archiv der civilistischen Praxis 208 (2008), 584-634. 
defined concretely ab initio who exactly will be bound to respect it and which conduct this concretely demands. New duty bearers, e. g. social media users, and new forms of behaviour, e. g. an abstention from twittering, could be (or become) required by the right.

The shift - at the end of the 18th century European Enlightenment philosophy - from the concept of duty to the concept of right as the foundational concept of the moral and legal fabric was extremely important. And maybe it is this shift that gives rise to some of the problems we are talking about today. Taking the right as the basis and starting point also means that one right can generate multiple duties, and that not only the addressee but also the substance is open and can evolve further, dynamically. For example, the human right to private life may evolve to an entitlement to have one's gender changed in a birth register. The right to privacy may evolve into a right to erasure on the internet. The right to bodily integrity may engender a right of protection against environmental pollution, and so on.

Another distinction is the one between public law and private law, a continental distinction. In the field of private law, rights and obligations can flow from legal instruments the parties conclude among themselves, notably contracts. In public law, rights are "given" by unilateral decrees. The best known type of rights are of course the fundamental rights guaranteed in the constitutions of rule of law-based states.

My prior examples were taken from domestic law, but rights have also codified in international law, beginning with the Universal Declaration of Human Rights of 1948. Those authors who deplore the "proliferation" of human rights point out that we now have 64 international human rightsrelated instruments with a total of 1,377 human rights provisions which a country that ratified all 64 instruments would have to comply with. Easily, these authors speak of "overregulation" here. ${ }^{7}$

I submit that the landscape of international law is currently not well conceptualised and that the legal status of the individual should be seen more nuanced. The idea that under international law individuals have only human rights which constitute them as international legal person is too simplistic. We should acknowledge that there are different types of rights, some fundamental and others not, also in international law. ${ }^{8}$ For example, individuals have rights under international environmental law, labour law, refugee law, or investment law. These rights are often connected to human rights, but not all of them are in themselves so important that they deserve the label of funda-

7 Jacob Mchangama and Guglielmo Verdirame, 'When Defending Liberty, Less Is More: The Danger of Human Rights Proliferation', Foreign Aff., 24 July 2013.

8 Anne Peters, Beyond Human Rights: The Legal Status of the Individual in International Law (Cambridge: Cambridge University Press 2016). 
mental right. The recognition of different levels of international rights could also counter the reproach of human rights inflation.

\section{The Rationale of Fundamental (Human) Rights}

What is the rationale or basis of rights? This is highly disputed with regard to human rights. ${ }^{9}$ It is often said that humans have human rights simply by virtue of being human. That is in a way the definition of human rights, their quintessential idea, but it is circular.

Historically, in the theological strand of natural law, the idea of rights for humans was explained with the immortal soul of man as the image of God. When this no longer held, the new secular strand of natural law pointed to the rational nature of humans.

Today, human dignity is often considered to be the basis of human rights. ${ }^{10}$ But this does not solve the problem, because dignity is a kind of quasireligious foundation, too. Why humans enjoy dignity begs the question. It is difficult to explain why only humans (as opposed to animals) should enjoy dignity and why therefore only humans should have human rights without drawing on metaphysics.

One of the foundational human rights texts, the US Declaration of Independence of 1776 - to which the US Pompeo Commission on "unalienable" rights alludes - begins with the wording: "We hold these truths to be selfevident, that all men are created equal, that they are endowed by their Creator with certain unalienable Rights, [...]." So the declaration pointed to the religious foundation but it also gives up reasoning by saying that it is "selfevident". Today, the British political philosopher Joseph Raz also "gives up" and writes that international human rights should be seen as "without foundations", simply arising out of the practice of tolerating foreign interference. ${ }^{11}$

However, it is not superfluous to think about the foundations, because the justifications of rights at least co-shape the expectations about their appropriate substance and about the appropriate holders, who should enjoy legal rights and who not.

A standard justification, closely related to man's ostensibly rational nature, is the protection of autonomy. Rights are legal institutions which protect the

9 In order not to exclude non-human rights-holders from the outset on, the word "fundamental rights" should be preferred. But because it is less common in English and in the discourse on international law, I will continue to write "human rights" here.

10 Christopher McCrudden, 'Human Dignity and Judicial Interpretation of Human Rights’, EJIL 19 (2008), 655-724.

11 Joseph Raz, 'Human Rights without Foundations' in: Samantha Besson and John Tasioulas (eds), The Philosophy of International Law (Oxford: Oxford University Press 2011), 321-337. 
autonomy of persons, so that they can choose for themselves what is a good life for them. ${ }^{12}$ This is of course a typical Western justification.

Another explanation, in a way the counterpoint, looks at the vulnerability of persons against forces of nature and brutality of other humans. This is a more feminine, or even feminist explanation of rights. ${ }^{13}$ Vulnerability has become an important legal concept in international human rights law. ${ }^{14}$ In order to protect especially vulnerable persons such as women, children, migrants, refugees or civilians in armed conflict, special sets of rights have been created. Vulnerability points more to the corporal, to the bodily existence of the "poor bare, forked animal" that is "man", as Shakespeare has King Lear say. ${ }^{15}$

\section{Ongoing Extensions of Human Rights}

\section{Which Rights?}

Rights, especially human rights, have been much extended in the 20th century. 30 years ago, many spoke of "generations" of human rights: liberal and political rights as the first generation, social, economic and cultural rights as the second generation, and group rights such as the right to self-determination or the right to peace (mentioned for instance in the African Charter of Human and Peoples' Rights) as the third generation. Today, some consider ecological rights to a clean and healthy environment and rights to environmental information (as enshrined for example in the Aarhus Convention), as a fourth generation. On the international plane, the political/civic rights on the one hand and economic/social rights on the other hand have been codified into different treaties at the same time (in 1966), to accommodate the divergence of opinion between the two political camps: the Western world found that the political rights were the real human rights, whereas the socialist bloc said that what actually matters first are the economic rights such as housing and food.

The "socialist" view is not implausible, variating the famous quip of Anatole France: Who needs the freedom to sleep under the bridges of Paris? ${ }^{16}$ It would be a "right" only for the rich.

12 James Griffin, On Human Rights (Oxford: Oxford University Press 2008).

13 Martha Albertson Fineman, 'The Vulnerable Subject: Anchoring Equality in the Human Condition', Yale Journal of Law and Feminism 20 (2008), 1-23.

14 Lourdes Peroni and Alexandra Timmer, 'Vulnerable Groups: The Promise of an Emerging Concept in European Human Rights Convention Law', I CON 11 (2013), 1056-1085.

15 William Shakespeare, King Lear: A Tragedy, London, printed by W. and J. Richardson and sold by B. White, in Fleet-Street 1770, Act III, Scene VI, at 107.

16 Anatole France, Le Lys Rouge (Paris: Calmann-Lévy 1894), 81. 


\section{The Oozing of Human Rights all Over International Law}

In contemporary international law, human rights of all types, under the mantra of the "unity and interdependence of all human rights", have gained much traction. They are impacting on the entire fabric of international law.

First, it has been acknowledged that each and every branch of international law must be interpreted in the light of human rights. Then human rights may function as a counterpoint, for example placing limits on the protection of foreign investors. ${ }^{17}$ The same applies to economic sanctions. Here, the obligation to interpret legal instruments in the light of human rights has become prominent. When the United Nations (UN) Security Council mandated UN member states to adopt targeted sanctions against terrorist suspects, the European Court of Human Rights (ECtHR) has asked the member states of the Council of Europe to interpret the relevant Security Council resolutions in the light of the rights guaranteed by the European Convention on Human Rights. ${ }^{18}$ Inversely and frequently, human rights are reinforcers and work in the same direction as the rules of other regimes interpreted in their light, for example in the law of refugees ${ }^{19}$ and in the international law of armed conflict. ${ }^{20}$

In many areas, an explicitly human rights-based approach is called for. This call arose around the turn of the millennium in the international law of development cooperation. Human Rights Commissioner Mary Robinson advocated a human rights-based approach to development, because human rights furnished clear legal benchmarks and allowed to assess the performance of development aid against these benchmarks. ${ }^{21}$ This approach contributed to legalising the entire field. Another example is the international law on combating natural disasters. The relevant International Law Commis-

17 See, e. g., ICSID, Bear Creek Mining Corporation v. Republic of Peru, ICSID case no. $\mathrm{ARB} / 14 / 21$, award of 30 November 2017, para. 406, notably partly dissenting opinion of Philippe Sands QC, paras 10-11.

18 ECtHR (GC), Al-Dulimi and Montana Management Inc. v. Switzerland, no. 5809/08 of 21 June 2016, para. 140.

19 See, e. g., Vincent Chétail, ‘Are Refugee Rights Human Rights?’ in: Ruth Rubio-Marín (ed.), Human Rights and Immigration: Collected Courses of the Academy of European Law (Oxford: Oxford University Press 2014), 19-72.

20 Helen Duffy, 'Trials and Tribulations: Co-Applicability of IHL and Human Rights in an Age of Adjudication' in: Law Applicable to Armed Conflict, Max Planck Trialogues on the Law of Peace and War Vol. 2 (Anne Peters and Christian Marxsen series eds) (Cambridge: Cambridge University Press 2019), 15-105.

21 Mary Robinson, A Voice for Human Rights (Philadelphia: University of Pennsylvania Press 2006), 299-307, print of: 'Bridging the Gap between Human Rights and Development: from Normative Principle to Operational Relevance', World Bank Presidential Lecture, Washington 3 December 2001. 
sion (ILC) text says that human rights must always be the yardstick. ${ }^{22} \mathrm{~A}$ fairly novel quest for rights-imbuement and alignment has been formulated in the field of international tax law. Here too, scholars argue that the law must be interpreted and applied in the light of (international) human rights. ${ }^{23}$

In all these issue areas, human rights work (or are asked to work) as a guideline for interpretation, and they fulfil further procedural functions. $\mathrm{Hu}-$ man rights impact assessments are required before transnational projects are started. For example, the UN Committee on Social Rights demands that states, before concluding new investment protection agreements or new international trade agreements, must conduct a human rights impact assessment. ${ }^{24} \mathrm{~A}$ similar procedural tool is human rights mainstreaming which means that all the elaboration, adoption, and implementation of legal instruments and policy instruments must at all times take human rights into account. ${ }^{25}$ To conclude, human rights have radiated into all subfields of international law and have thereby become ubiquitous.

\section{Rights Against Whom? - New Duty Bearers}

Besides the extension of rights in substance, the duty bearers have also been expanded. Human rights had been invented as rights against the state because the state has the overwhelming both physical and legal means to threaten and destroy humans, beginning with putting them in jail or camps, killing them with help of the state's army and police force, torturing them, and so on.

In today's world of global capitalism, transnational business actors also have enormous power over persons. They have the power to harm, hurt and even

22 Art. 2 of the Draft Articles on the Protection of Persons in the Event of Disasters, adopted by the International Law Commission at its sixty-eighth session, in 2016, and submitted to the General Assembly as a part of the Commission's report covering the work of that session (A/71/10); ILCYB 2016, Vol. II, Part Two.

23 Olivier De Schutter, Nicholas J. Lusiani and Sergio Chaparro, 'Re-righting the International Tax Rules: Operationalising Human Rights in the Struggle to Tax Multinational Companies', The International Journal of Human Rights 24 (2020), 1370-1399, DOI: 10.1080/ 13642987.2020.1816971.

24 UN Committee on Economic, Social and Cultural Rights (CESCR), General Comment No. 24 on State Obligations under the International Covenant on Economic, Social and Cultural Rights in the Context of Business Activities of 23 June 2017 (UN Doc E/C.12/GC/ 24), para. 13. See also UN Human Rights Council, Open-ended Inter-Governmental Working Group (OEIGWG) Chairmanship, Second revised draft of 6 August 2020, <https://www. ohchr.org>, Art. 14(5).

25 See with a view to the UN: Gerd Oberleitner, 'A Decade of Mainstreaming Human Rights in the UN: Achievements, Failures, Challenges, NQHR 30 (2008), 359-390. 
destroy human lives either directly by hiring them for labour in inhumane, dangerous, unhealthy and low-paid work conditions, or indirectly by polluting the environment, dumping waste, and setting up firms in infrastructure by drawing on forced labour or with help of the military in authoritarian states.

The need to reign in the power of business is therefore widely acknowledged. I personally think that simply tying business to the existing international human rights is not the solution. We need a better adapted toolkit which takes into account the different type of power that business deploys and which does not let the states off the hook. This is also the line which the draft of a Legally binding instrument to regulate, in international buman rights law, the activities of transnational corporations and other business enterprises, currently discussed in the United Nations Human Rights Council, is taking. ${ }^{26}$

\section{Where do Rights Reach?}

Besides the radiations of human rights into new areas and besides the extension of the addressees of rights, their spatial scope has been expanded, too. The question is where human rights should deploy their effects. In our globalised world everything is connected. Police and military action or surveillance activity crosses borders. For example, the United Kingdom set up internment facilities in Iraq, and our emails travel over servers in Ireland and the United States. When the European Union grants payments to European farmers and gives export subsidies, this has repercussions for Asian and African farmers who cannot sell their products easily in the European Union.

All these transnational activities or transnational effects have been examined under the perspective of human rights. The question then is whether, e.g. European states are bound to respect the human rights of people, e. g. in Iraq, Bangladesh, or India, and when and under what conditions. These questions are discussed under the heading of extraterritorial binding force. They are extremely complicated and not yet resolved. ${ }^{27}$

\section{Rights Holders: Rights for Whom?}

When rights were invented, in the 18th century, they were called universal, but in reality they were reserved for a very small circle of the

26 OEIGWG second draft (n. 24).

27 Elif Askin, 'Economic and Social Rights, Extraterritorial Application' in: Rüdiger Wolfrum (ed.), Max Planck Encyclopedia of International Law (Oxford: Oxford University Press 2019). 
privileged happy few. People without property, people who did not pay taxes, women, peasants, and slaves did not enjoy any rights. The contradiction between the universalist language and the exclusivity of rights holders was not seen.

Only gradually and over several centuries, the circle of rights holders has been extended, most recently even beyond humans, to animals and natural entities. ${ }^{28}$ Courts in Argentina, Colombia, India, and Pakistan have awarded certain rights to animals, notably apes. ${ }^{29}$ The courts here often point to the intellectual and emotional features of the animals and mostly to their sentience, that is their capacity to feel pain and suffer in confinement.

And courts and statutes in the same countries have acknowledged rights of natural entities, ranging from the Amazonian forest ${ }^{30}$ over the river Ganges ${ }^{31}$ to the volcano Taranaki in New Zealand. ${ }^{32}$ These decisions often rely on the spiritual heritage of indigenous populations, and they justify the rights of nature both by practical needs for stronger legal protection and by the holy nature of the entities, rivers or mountains.

\section{Critiques of Rights}

Given the extraordinary career of the legal institution of rights it is not surprising that critique is being voiced. Critics speak of "rights inflation",

28 On rights of natural entities seminally Christopher D. Stone, 'Should Trees Have Standing? Toward Legal Rights for Natural Objects', S. Cal. L. 45 (1972), 450-501. For animal rights: Saskia Stucki and Visa Kurki, 'Animal Rights' in: Mortimer Sellers and Stefan Kirste (eds), Encyclopedia of the Philosophy of Law and Social Philosophy (Heidelberg: Springer 2020).

29 S.Ct. of India, Animal Welfare Board of India v. Nagaraja and others, Civil appeal no. 5387, 7 May 2014; Tercer Juzgado de Garantías Mendoza (Argentina), case no. P-72.254/15, 3 November 2016 - Chimpanzee Cecilia; Colombian Supreme Court of Justice, Corte Suprema de Justicia (judge Luis A. Tolosa), AHC4806-2017, Radicación no. 17001-22-13-000-201700468-02, 26 July 2017 (on the bear Chucho; overturned by the Columbian Constitutional Court); Islamabad High Court, Islamabad, W. P. no. 1155/2019, Islamabad Wildlife Management Board v. Metropolitan Corporation Islamabad, 21 May 2020 (on a zoo elephant).

30 Constitutional Court of Colombia, T-622 of 10 November 2016 - River Atrato.

31 High Court of Uttarakhand, Mohd Salim v. State of Uttarakhand E others, writ petition (PIL) no. 126/2014, decision of 20 March 2017, para. 19, overturned by Supreme Court of India, State of Uttarakhand E others v. Mohd Salim E others, Petition for Special Leave to Appeal 016879/2017, 7 July 2017.

32 The Crown and Ngā Iwi o Taranaki, Te Anga Pūtakerongo, Record of Understanding for Mount Taranaki, Pouakai and the Kaitake Ranges, 20 December 2017 (notably sections 5.2.2.; 5.2.3.; 5.2.7.; 5.5.2.; 5.14). In scholarship Katherine Sanders, "Beyond Human Ownership?” Property, Power and Legal Personality for Nature in Aotearoa New Zealand', J. Envtl. L. 30 (2018), 207-234. 
"rights proliferation", 33 "rights overreach", "rightsification", ${ }^{34}$ and of an undue "right-ing" 35 of legal regimes and fields. This criticism is not without merit. It can be questioned whether we really need a right to globalisation, ${ }^{36}$ a right against corruption, ${ }^{37}$ a right to the city, ${ }^{38}$ a right to a microcredit, ${ }^{39} \mathrm{a}$ right to the internet, ${ }^{40}$ and a right to breastfeeding, ${ }^{41}$ to mention only some of the new rights currently proposed.

The backlash against rights feed on different intellectual paradigms, and is both analytical and political. Some critique is levelled against the institution of rights as such, for example in opposition to a legal order based on duties ${ }^{42}$ or even on virtues. ${ }^{43}$ Or, for example Roberto Gargarella deplores that in Latin-American constitutionalism, the focus on rights neglects what Gargarella calls the "engine room" of the constitution, namely the institutions such as parliaments and the executive branch. ${ }^{44}$

In a neo-Marxist framework, rights are only a superstructure over the material conditions of production and in the end only serve to protect the bourgeois property. ${ }^{45}$ Critical legal studies and large parts of the TWAIL

33 Mchangama and Verdirame (n. 7).

34 John Gershman and Jonathan Morduch, 'Credit is not a Right' in: Tom Sorell and Luis Cabrera (eds), Microfinance, Rights and Global Justice (Cambridge: Cambridge University Press 2015), 14-26 (21).

35 The term 'righting' was coined by Karen Knop and applied in a critical spirit to the law of occupation by Aeyal Gross (Aeyal Gross, The Writing on the Wall: Rethinking the International Law of Occupation (Cambridge: Cambridge University Press 2017), chapter 5).

36 Michael D. Pendleton, 'A New Human Right: The Right to Globalization', Fordham Int'l L. J. 22 (1999), 2052-2095.

37 Ndiva Kofele-Kale, 'The Right to a Corruption-Free Society as an Individual and Collective Human Right: Elevating Official Corruption to a Crime under International Law', Int'l Law. 34 (2000), 149-178; Andrew Brady Spalding, 'Corruption, Corporations and the New Human Right', Washington University Law Review 91 (2014), 1365-1428.

38 David Harvey, 'The Right to the City', New Left Review 53 (2008), 23-40. The author proclaims this right "as both working slogan and political ideal" (at 40).

39 Cf. John Gershman and Jonathan Morduch (n. 34), 21.

40 Tommaso Edoardo Frosini, 'Access to Internet as a Fundamental Right', Italian Journal of Public Law 5 (2013), 226-234.

41 Mathilde Cohen, 'Toward an Interspecies Right to Breastfeed', Animal Law Review 26 (2020), 1-40.

42 Onora O’Neill, Justice Across Boundaries: Whose Obligations? (Cambridge: Cambridge University Press 2016).

43 John Milbank, 'Against Human Rights: Liberty in the Western Tradition' in: Costas Douzinas and Conor Gearty (eds), The Meanings of Rights: The Philosophy and Social Theory of Human Rights (Cambridge: Cambridge University Press 2014), 39-70.

44 Roberto Gargarella, Latin American Constitutionalism, 1810-2010: The Engine Room of the Constitution (Oxford: Oxford University Press 2013).

45 Karl Marx, 'On the Jewish Question', in: Marx and Engels, Collected Works Vol. 3 (18431844) (International Publishers, New York 2005), 146, 164. Written in the autumn of 1843 , printed according to the journal, first published in the Deutsch-französische Jahrbücher, 1844. 
movement, some post-colonial approaches, and also some feminist approaches are in some respects a heir to this view.

A different attack comes from thinkers who place high value on democracy and the political process. This is much en vogue in the United Kingdom. Thinkers along these lines see rights as an undue legalisation which takes away things to be decided in the political process and gives also too much power to constitutional courts which adjudicate on these rights. ${ }^{46}$

So the critique here is both the reproach of a "depoliticisation" and of an inappropriate "gouvernement des juges". This unwanted government of judges is of course seen as more problematic when the judges are international judges, for example sitting in Strasbourg. This criticism risks to flow into the populist pushback against courts and international organisations as supposedly elitist institutions which do not pay attention to what "the people" really wants.

Another strand of critique is more communitarian, sceptical of what Mary Ann Glendon calls a mere "rights talk" in a "nation under lawyers". 47 This line of thought opines that a society can hold together only if people do not constantly reclaim their egoistic rights, but are ready to compromise, are more solidary. These scholars place more emphasis on responsibility and overall build more on what we might call civic virtue.

An important strand of critique particularly attacks the endorsement and protection of rights on the international level. Here the well-known objection is culture-based. The claim is that human rights are a Western invention which do not fit in the rest of the world, notably to "Asian values". ${ }^{48} \mathrm{~A}$ related reproach is that human rights have been imposed and were and still are used as a pretext for colonisation and "informal empire". What was called "civilisation" was in reality exploitation, subjugation, and extermination of non-European peoples. Post-colonial critics warn that this perverse civilising mission is continuing in the shape of intervention, war, and economic domination. Their reproach is that today even, rights have not been properly and fully decolonised, because rights are de facto being withheld from groups of

See for a contemporary reprisal: e.g. Anna Chadwick, Law and the Political Economy of Hunger (Oxford: Oxford University Press 2019).

46 See, e. g., Jeremy Waldron, 'A Rights-Based Critique of Constitutional Rights', Oxford J. Legal Stud. 13 (1993), 18-52.

47 Mary Ann Glendon, Rights Talk: The Impoverishment of the Political Discourse (New York: The Free Press 1991); Mary Ann Glendon, A Nation under Lawyers: How the Crisis in the Legal Profession is Transforming American Society (Cambridge Mass.: Harvard University Press 1996).

48 The term was coined by Lee Kuan Yew, Singapore's leading politician (Prime Minister from 1959-1990, member of cabinet from 1990-2004). See Michael B. Barr, 'Lee Kuan Yew and the “Asian Values” Debate', Asian Studies Review 24 (2000), 309-334. 
persons considered inferior. ${ }^{49}$ The infinite detainment of terror suspects, the inhumane conditions in asylum camps, the Western consumers' complicity in exploiting labourers and poisoning the environment in the cheap sites of production for business controlled from the north are examples in point.

At the other end of the spectrum, the neo-liberal assault on international human rights is specifically directed at some rights, notably against the current intensification of international social rights. ${ }^{50}$ For example, Jacob Mchangama and Guglielmo Verdirame point out that it is a problem to mention torture in North Korea in the same breath as cutting back development aid, and calling both human rights violation. ${ }^{51}$

To sum up, these various critiques come from totally different and even opposite ideational and ideological camps. One could say that there is an unholy alliance against rights among the different "theories" spanning from Marxism to neo-liberalism.

\section{Reasons for the Backlash}

What are the reasons for this backlash now? Several factors seem to be playing together.

First, there is disillusionment. Human rights (both international and constitution-based) have been expanded on paper without sufficient attention to realising the existing rights. The rights have become paper tigers. Kathryn Sikkink therefore calls for more responsibility for implementing them. ${ }^{52}$

Second, there is a repulse against double standards and hypocrisy of the West. ${ }^{53}$ States of the non-Western world are asked (with carrots and sticks, for example with conditionalities) to respect human rights while they see that at the same time in some rich states of the North-West refugees are detained, migrant families are separated, drone strikes produce excessive civilian casualties, and the Western lifestyle is seen to benefit from unhealthy working conditions and cheap labour in the Southern production site countries.

49 Colin Samson, The Colonialism of Human Rights: Ongoing Hypocrisies of Western Liberalism (Cambridge: Polity Press 2020).

50 Eric Posner, The Twilight of Human Rights Law (Oxford: Oxford University Press 2014).

51 Mchangama and Verdirame (n. 7). The authors do not mention torture in secret CIA facilities.

52 Kathryn Sikkink, The Hidden Face of Rights: Toward a Politics of Responsibilities (New Haven: Yale University Press 2020), 33.

53 See notably Stephen Hopgood, The Endtimes of Human Rights (Ithaca, NY: Cornell University Press 2013). 
Third, there is a globalisation fatigue. The wealth trickle down effects through trade liberalisation and foreign investments have not reached everyone, not the most poor and abject. Roughly speaking, material inequality of wealth and income is rising, in different degrees both intra-country-wise and across countries. ${ }^{54}$ Also the poorer class in the wealthy states has not benefitted much from globalisation but rather feels threatened by it. ${ }^{55}$

A fourth factor is digitalisation. People now see the different living conditions at the other end of the world. In former times, a young man from sub-Saharan Africa did not know exactly how we lived here. Now he is confronted with it every day, even in a much idealised way, on social media, films, YouTube, etc. Unlike maybe still some decades ago, people probably no longer accept it as their fate to be born on the wrong side of the globe.

Fifth and most troubling is the fact that the backlash is in line with the shift of political and economic power in the world. States that have traditionally applied a top-down governance style and which lack a deeply rooted rule of law and democratic tradition are on the rise. Besides, even traditional democracies are eroding from the inside. This overlaps with a power gain of states built on collectivist, anti-individualist traditions, and/or non-secular traditions and even religious fundamentalism. This matters for the question of rights, because - simplistically speaking - the religion-based ethics are duty-based ethics, not rights-based, starting with the duty towards God. For me as a lawyer the most sobering observation is that rights are in decline while this power shift is occurring. The parallelism might be a coincidence but it might also show that the law is only an epiphenomenon to politics and the economy. When these spheres change, the law follows suit.

\section{Response: The Work and Benefits of Rights}

Against the critique from left to right, I would like to argue in favour of rights from a practical perspective, without speculating too much about the justification, simply pointing to the benefits of rights. This practical approach seeks to do justice to the fact that the intellectual backlash is apparently not

54 World Bank, Poverty and Shared Prosperity 2020: Reversal of Fortune, Washington, DC: World Bank 2020; Price Waterhouse Coopers and UBS (Switzerland), Riding the Storm: Market Turbulence Accelerates Diverging Fortunes, Billionaires Insights, pwc and UBS, 2020.

55 Branko Milanović, Global Inequality: A New Approach for the Age of Globalization (Harvard: Harvard University Press, 2016). 
deterring people all over the world, from Venezuela over Nigeria, Bangladesh, and Hong Kong from reclaiming their rights. Obviously, they see a benefit in them - however shaky the theory might be.

So let us look at the good job that rights perform. First of all rights have classically been considered a vehicle for emancipation. Importantly, their idealism and dynamism can be used both as a force of revolution building a radically new political order and more modestly as a tool for conciliation and coalition-building. This "chameleonism" of rights contributes to their practical appeal and usefulness. ${ }^{56}$ It has been said that rights transform victims into citizens. ${ }^{57}$ This is surely extremely valuable, and continues to be valued. However this rationale of rights could not explain animal rights, because animals can never reclaim their rights in the streets or go to court by themselves.

The second benefit is that rights, for example the right to bodily integrity, the right to move around freely, or the rights to housing and food, protect the vulnerable body and not only the intellect. It is telling that the writ of habeas corpus was historically the first human right. Rights protect precisely this imperfect body. Rights are not the price for the smartest and the fittest, for the best and the brightest. Tying rights to capacities and conditioning them on the possession of qualities and capabilities such as rationality, selfawareness, or meta-cognition, ultimately risks to end up in ableism, in discriminating and excluding those who are intellectually weak, physically disabled, and mentally disturbed. But exactly those members of society need rights the most. This could then include animals, too.

Crucially, rights trigger an obligation to justify harmful activity. If a right to bodily integrity is the starting point of juridical reflection, taking away the living space, detaining, mutilating, or killing somebody cannot be done without further explanation, not for trivial and banal reasons. With rights as the default position, such action needs to be specifically justified in a rational procedure where grounds must be mentioned, explained, and also proven in certain forms. The new practice of "human-rights based approaches" in all fields of (international) law, including mainstreaming and impact-assessments, counts on exactly this discursive function. Because rights trigger a justificatory process, they have been fittingly called, not "trumps" as Ronald Dworkin would have it, but prima facie legal positions. The legal institution of rights leads to a culture of justification as opposed to a culture of authority,

56 Conor Gearty, 'Do Human Rights Help or Hinder Environmental Protection?', Journal of Human Rights and the Environment 1 (2010), 7-22 (21).

57 Cass Sunstein, 'Rights and Their Critics', Notre Dame L. Rev. 70 (1999), 727-768 (754). 
to quote the legal scholar and South African Constitutional Court judge, Etienne Mureinik, who had fought against the system of apartheid. ${ }^{58}$

This suggests that rights should not only be codified and protected at the domestic level but also at the international plane, because the burden shifting function of rights is needed also in transboundary constellations, and deserves the additional safety valve which international monitoring provides. The discursive function of rights is also beneficial for animals as a shield against gratuitous harm. From this perspective, the recognition of animal rights is warranted.

The critique against international rights as being just a moral crusade of the West is to a large extent - I submit - unfounded. It is true that throughout history, rights have been abused by Western invaders and colonisers. However, the current push-back against rights is mostly pretextual. It is a coverup of the elites, of the ruling political parties, of dictators, oligarchs, and the superrich in countries whose leaders do not care or in any case do not listen and are not accountable to the population.

Rights have always been reclaimed and fought for exactly against the dominant culture and against the establishment. Rights were reclaimed by European middle-class against the nobility that was in power, by laypersons against the church, and by women against men. Today, an open question is whether rights should also be acknowledged to animals although they cannot fight for these rights themselves.

Of course, especially the international endorsements of rights must grant a certain deference to the diversity of living contexts on the ground, as for example the Strasbourg Court does. But every margin of appreciation left to local law appliers has limits. The real question is where and how to draw those limits. This question should be answered in light of the reason for allowing variations in human rights standards. The main reason is the positive value of cultural diversity.

However, habits and traditions are not per se worth protecting simply because we call them culture. There was a culture of binding women's feet, there still is a culture of mutilating women's genitals, and a culture of eating animals. A collection of stupidities and cruelties is not worth protecting as such, as little as the prohibition for women to drive a car and the practice of marrying children at the age of 10 is worth upholding. In order to find out whether women want to drive a car or to be married at the age of 10 to a $30+$ year old man we must ask the women, not their husbands. To conclude, the reproach of overblowing international human rights can be effectively coun-

58 Etienne Mureinik, 'A Bridge to Where? Introducing the Interim Bill of Rights', SAJHR 10 (1994), 31-48. 
tered by two moves. First, a margin of appreciation in their application to different circumstances needs to be accepted. Secondly, "simple", non-fundamental rights of individuals in international regimes ranging from international labour law over migration law to environmental law need to be acknowledged, because these are apt to change the structure of legal analysis without overburdening the idea of human rights.

\section{Conclusions}

Rights, for human and possibly also for non-human animals, have not "popped", and should not be thrown into the trashbin of history. Quite to the contrary, they are an eminently useful legal institution which must be upheld and refined. In order to determine which interests and which behaviour need the specific and stronger protection in the form of rights, we have to ask people on the ground. Many are already giving an answer, namely by voting with their feet and migrating away from societies in which their needs are not met. Of course "meeting their needs" does not necessarily require legal protection in form of rights but it probably includes rights. So we have to study more closely and empirically what people want. An ongoing international social science project based on polls in the entire world finds that the preferences of people change indeed with the change of the society they live in. ${ }^{59}$ When they are threatened in their physical existence by violence, criminality, war, and hunger, they favour what the researchers call traditional values such as hierarchy in the family and the like. When their physical existence is secure, with less war, less crime, and less hunger, then they cherish more autonomy and choices.

These plausible results explain why in our situation of globalisation fatigue, growing wealth disparity, new insecurity due to macro-trends such as global warming, environmental degradation, and not the least pandemics, a turn back to traditional values is occurring. But even in this climate we should never forget that rights are - to paraphrase Rosa Luxemburg60 needed exactly by the others, the ones who are deprived, and not by those who have the say and who have everything.

Anne Peters

$59<$ http://www.worldvaluessurvey.org $>$. The "world value survey" has been founded by the US political scientist Ronald Inglehart.

60 Rosa Luxemburg, 'Freiheit ist immer Freiheit des anders Denkenden' in: Paul Levi (ed.), Die Russische Revolution: Eine kritische Würdigung. Aus dem Nachlass von Rosa Luxemburg (Berlin: Verlag Gesellschaft und Erziehung 1922), 109. 